\title{
PENGARUH MODEL PEMBELAJARAN PROBLEM BASED INSTERUCTION (PBI) TERHADAP KEMAMPUAN SISWA BERPIKIR KRITIS DI KELAS XI SMA NEGERI 4 KOTA BENGKULU
}

\author{
Indah Cucurostanti ${ }^{1}$ dan Mety Herlina ${ }^{2}$ \\ ${ }^{1}$ Universitas Muhammadiyah Bengkulu \\ ${ }^{2}$ Universitas Muhammadiyah Bengkulu
}

\begin{abstract}
This study aims to determine the effect of the Problem Based Instruction (PBI) learning model on the ability of students to think critically in class XI SMA Negeri 4 Bengkulu City. This study uses an experimental method, the sample of the population in this study are two classes selected by the Simple Random Sampling technique. Data analysis techniques using 1. Normality Test 2. Homogeneity Test 3. T-Test (Hypothesis Test). Based on the average value of students 'critical thinking skills in the class using the Problem Based Instruction learning model is 77.74, while the average value of students' critical thinking skills in conventional classes is 70.27. And after the t-test, a significant value of students 'critical thinking abilities is obtained, with Tcount 2.899 and Ttable 2.05, then Tcount 2.899> Ttable 2.05, thus based on the hypothesis it can be concluded that there is a significant influence on the value of students' critical thinking abilities using Problem Based Instruction learning model (H1 accepted and H0 rejected).
\end{abstract}

Keywords: Critical Thinking Skills, Problem Based Instruction (PBI), Conventional models.

Abstrak: Penelitian ini bertujuan untuk mengetahui pengaruh model pembelajaran Problem Based Instruction (PBI) terhadap kemampuan siswa berpikir kritis di kelas XI SMA Negeri 4 Kota Bengkulu. Penelitian ini menggunakan metode eksperimen, sampel dari populasi dalam penelitian ini adalah dua kelas yang dipilih dengan teknik Simple Random Sampling. Teknik analisis data dengan menggunakan 1. Uji Normalitas 2. Uji homogenitas 3. Uji-t (Uji Hipotesis). Berdasarkan nilai rata-rata Kemampuan berpikir kritis siswa pada kelas yang menggunakan model pembelajaran Problem Based Instruction adalah 77,74, sedangkan nilai rata-rata kemampuan berpikir kritis siswa pada kelas konvensional adalah 70,27. Dan setelah dilakukan Uji-t diperoleh nilai signifikan kemampuan berpikir kritis siswa yaitu dengan Thitung 2,899 dan Ttabel 2,05 maka Thitung 2,899> Ttabel 2,05 maka dengan demikian berdasarkan hipotesis dapat disimpulkan bahwa ada pengaruh yang signifikan dari nilai kemampuan siswa berpikir kritis yang meggunakan model pembelajaran Problem Based Instruction (H1 diterima dan H0 ditolak).

Kata Kunci: Kemampuan Berpikir Kritis, Problem Based Instruction (PBI), Model Konvensional.

\section{PENDAHULUAN}

Pendidikan adalah wadah bagi para generasi penerus bangsa agar dapat berpikir kritis dan kreatif sehingga Indonesia bisa menjadi negara maju yang mampu bersaing dengan negara lain dari segi pendidikan.Salah satu proses yang termaksud dalam pendidikan yaitu belajar (Wati dan Hermanto, 2015).

Belajar adalah proses usaha yang dilakukan seseorang untuk memperoleh perubahaan tingkah laku yang baru secara keseluruhaan, sebagai hasil pengalamannya sendiri dalam interaksi dengan lingkungannya (Hamdani, 2011). Kemampuan manusia untuk belajar merupakan karakteristik penting yang membedakan manusia dengan makhluk hidup lainnya.Belajar mempunyai keuntungan baik individu maupun bagi masyarakat. Bagi individu, kemampuan untuk belajar secara terus-menerus akan memberikan konstribusi terhadap perkembangan kualitas hidupnya. Sedangkan bagi masyarakat, belajar mempunyai peran yang penting dalam mentransmisikan budaya dan pengetahuan dari generasi ke generasi Bell-Gredler (dalam Baharuddin dan Wahyuni, 2009).

Dalam kegiatan belajar mengajar, berbagai upaya dilakukan untuk mengembangkan pembelajaran Biologi agar dapat mencapai tujuan, dan menciptakan suasana belajar yang lebih menyenangkan, serta lebih bermakna. Melalui model pembelajaran kontekstual, pembelajaran selalu dikaitkan dengan kehidupan sehari-hari sehingga siswa lebih mudah memahami isi pelajara. Pengaitan isi pelajaran dengan lingkungan sekitar akan memuat pembelajaran lebih bermakna (meaning learning) karena siswa mengetahui pelajaran yang didapat di kelas bermanfaat dalam kehidupan sehari-hari.Belajar biologi bukan hanya berhadapan dengan teori dan konsep saja,melainkan harus melakukan sesuatu, mengetahui, dan memecahakan masalah yang terkait dalam pembelajaran Biologi (Agustina, 2011).

Salah satu kemampuan yang diukur dalam pembelajaran biologi yaitu kemampuan berfikir kritis. Menurut Dwijananti dan Yulianti (2010), Berpikir kritis merupakan kegiatan menganalisis ide atau gagasan ke arah yang lebih spesifik, membedakan secara tajam, memilih, mengidentifikasi, mengkaji dan mengembangkannya ke arah yang lebih sempurna. Proses mental ini menganalisis ide dan informasi yang diperoleh dari hasil pengamatan, pengalaman, akal sehat atau komunikasi.

Berdasarkan observasi awal di sekolah yang akan menjadi tempat penelitian yaitu SMA Negeri 4 Kota Bengkulu di dapatkan informasi dari salah satu 
guru yang mengajar biologi yaitu Ibu Martini,S.Pd berdasarkan hasil observasi diketahui bahwa hasil belajar siswa masih rendah, yang terlihat dari belum tercapainya kreteria ketuntasan minimal (KKM) 70. Hal ini dapat diketahui dari penilaian hasil ujian akhir semester sebelumnya siswa kelas XI IPS 2 nilai rataratanya yaitu 61,4 dan untuk kelas XI IPS 3 nilai rataratanya yaitu 57,8. Dan dalam pembelajaran biologi guru menerapkan metode pembelajaran yang dominan ceramah dan metode diskusi biasa, guru belum menggunakan model pembelajaran yang bervariasi.

Sebagai salah satu upaya yang dapat dilakukan oleh guru untuk meningkatkan kualitas proses pembelajaran, dengan cara menggunakan model pembelajaran yang dapat meningkatkan kemampuan berfikir kritis siswa. Salah satunya dengan menggunakan model pembelajaran Problem Based Instruction (PBI).

Menurut Trianto (2009), Model Problem Based Instruction merupakan suatu model pembelajaran yang didasarkanpada suatu permasalahan yang membutuhkan penyelidikan autentik yakni penyelidikan yang membutuhkan penyelesaian nyata dari permasalahan yang nyata. Problem based instruction ini tidak dirancang untuk membantu guru memberikan informasi sebanyakbanyaknya kepada siswa, melainkan untuk membantu siswa mengembangkan kemampuan berpikir, pemecahan masalah, dan keterampilan intelektual.

Dari hasil penelitian terdahulu (Dwijananti dan Yulianti, 2010) tentang pengembangan kemampuan berpikir kritis mahasiswa melalui pembelajaran problem based instruction pada mata kuliah fisika lingkungan. Menyatakan bahwa pembelajaran menggunakan model Problem Based Instruction mampu meningkatkan nilai rata-rata kemampuan berfikir kritis mahasiswa, berdasarkan data bahwa dengan menggunakan model pembelajaran Problem Based Instruction, mahasiswa dapat mengembangkan kemampuan berfikir kritis dan pemecahan masalah.

\section{METODE}

Adapun jenis penelitian yang digunakan yaitu Jenis Penelitian eksperimen yang bertujuan untuk menguji hipotesis dengan rancangan penelitian dimana setiap kelas di beri perlakuan yang berbeda. Pada kelas eksperimen kemampuan berpikir kritis siswa dilihat dengan menggunakan Model pembelajaran Problem Based Instruction (PBI) sedangkan pada kelas kontrol menggunakan pembelajaran konvensional. Sesuai dengan jenis penelitian dan masalah yang dikemukakan sebelumnya, maka rancangan penelitian ini menggunkan dua kelas yaitu satu kelas eksperimen dan satu kelas kontrol.

Untuk memperoleh data tentang kemampuan berpikir kritis siswa digunakan alat pengumpulan data yang berbentuk tes kemampuan berpikir kritis siswa, tes tersebut berdasarkan pada materi yang diberikan dan sesuai dengan kurikulum yang berlaku. Tes yang digukan dalam penelitian ini adalah seperangkat soal uraian tes awal dan tes akhir.

\section{HASIL PENELITIAN DAN PEMBAHASAN} Hasil

Berdasarkan hasil penelitian yang telah dilakukan terhadap kegiatan belajar mengajar biologi di kelas XI IPS 3 dan XI IPS 2 pada pokok bahasan sistem saraf. Pada setiap kelas XI IPS 3 dan XI IPS 2 sebelum di beri perlakuan, terlebih dahulu diberi pretest untuk mengetahui kemampuan awal berpikir kritis siswa tentang pokok bahasan sistem saraf. Berdasarkan tabel di atas terlihat bahwa kemampuan awal berpikir kritis siswa masih rendah, terlihat dari rata-rata pretest siswa di kelas XI IPS 3 52,96 sedangkan di kelas XI IPS 2 49,17.

Sebelum melakukan uji hipotesis menggunakan uji-t, perlu dilakukan uji persyaratan yaitu uji normalitas dan uji homogenitas varian. Uji normalitas digunakan untuk menguji apakah data dari penelitian diperoleh dari populasi berdistribusi normal atau tidak. pada penelitian ini uji normalitas menggunakan uji Kolmogorov _ Smirnov. Dengan ketentuan jika sig > 0,05 maka H0 diterima (berdistribusi normal) sedangkan jika sig < 0,05 maka $\mathrm{Ha}$ diterima (berdistribusi tidak normal). Berikut rekapitulasi perhitungan uji normalitas pretest tentang kemampuan berpikir kritis siswa pada pokok bahasan sistem saraf.

\section{Kemampuan Berpikir Kritis Siswa}

Data nilai kemampuan siswa berpikir kritis pada pokok bahasan sistem saraf. Pada kelas XI IPA 3 dan XI IPA 2 terdapat perbedaan secara signifikan. dapat dilihat pada tabel berikut:

Tabel 1. Perhitungan uji-t nilai postest kemampuan berpikir kritis Independet Samples Test

\begin{tabular}{clll}
\hline & & \multicolumn{1}{c}{ Hasil } & Belajar \\
\cline { 3 - 4 } & & \multicolumn{1}{c}{$\begin{array}{c}\text { Equal Variances } \\
\text { assumed }\end{array}$} & $\begin{array}{c}\text { Equal Variances } \\
\text { assumed }\end{array}$ \\
\hline \multirow{2}{*}{ Levene's test for equality } & F & Sig & 1,931 \\
of variances t-test equality & T & 0,123 & \\
& Df & 2,899 & 2,898 \\
of means & Sig. (2- Tailed) & 28 & 27,993 \\
& & 0,007 & 0,007 \\
\hline
\end{tabular}




\begin{tabular}{lll} 
Mean Difference & 7,103 & 7,103 \\
Std. Error Difference & 2,450 & 2,450 \\
95\% Confidence & 2,084 & 2,087 \\
interval of the lower & & \\
Difference Upper & 12,122 & 12,119 \\
\hline
\end{tabular}

Dapat diilihat dari hasil uji-t dengan Thitung 2,899 dan Ttabel 2,05 maka Thitung 2,899 > Ttabel 2,05 sehingga $\mathrm{H} 1$ diterima dan $\mathrm{H} 0$ ditolak (terdapat pengaruh secara signifikan).

\section{PEMBAHASAN}

Berdasarkan pada data analisis hasil uji normalitas postest pada tabel 4.6 di dapat kan bahwa data nilai berpikir kritis siswa berdistribusi normal, selanjutnya dilakukan uji homogenitas postest pada tabel 4.7 di dapat kan bahwa data nilai berpikir kritis siswa berasal dari sampel yang homogen. Setelah data yang di uji memenuhi kedua uji persyaratan, maka data tersebut dilanjutkan dengan pengujian hipotesis menggunakan uji-t untuk mengetahui pengaruh kemampuan siswa berpikir kritis dengan menggunakan model pembelajaran Problem Based Instruction. Dengan ketentuan uji-t Jika thitung > ttabel maka H1 diterima dan H0 ditolak (terdapat pengaruh yang signifikan) sedangkan, Jika thitung < ttabel maka H0 diterima dan H1 ditolak (tidak terdapat pengaruh yang signifikan) dengan daftar distribusi df $5 \%=28$ maka nilai ttabelnya 2,05. Sehingga diperoleh nilai uji-t dengan Thitung 2,899 dan Ttabel 2,05 maka Thitung 2,899 > Ttabel 2,05 maka dengan demikian berdasarkan hipotesis dapat disimpulkan bahwa terdapat pengaruh yang signifikan dari nilai kemampuan siswa berpikir kritis (postest) dengan meggunakan model pembelajaran Problem Based Instruction (H1 diterima dan $\mathrm{H} 0$ ditolak).

Selain itu juga berdasarkan data hasil postest kemampuan siswa berpikir kritis yang telah di dapat pada kelas yang menggunakan model pembelajaran Problem Based Instruction mendapat nilai postest dengan jumlah nilai rata-rata 77,47. Sedangkan pada kelas yang menggunakan model pembelajaran konvensional mendapatkan nilai rata-rata yaitu 70,27. Maka dari hasil postest kemampuan siswa berfikir kritis dapat disimpulkan bahwa terdapat pengaruh model pembelajar Problem Based Instruction terhadap kemampuan siswa berpikir kritis.

Hal tersebut sesuai pada penelitian terdahulu, seperti pada penelitian Purwaningsih (2013), Tentang Model Pembelajaran Problem Based Instruction Untuk Meningkatkan Keaktifan Belajar Dan Kemampuan Berpikir Kritis Siswa. Hasil penelitian menunjukkan bahwa penerapan model pembelajaran Problem Based Instruction (PBI) dapat meningkatkan keaktifan belajar dan kemampuan berpikir kritis siswa.

Kemampuan siswa berpikir kritis dengan menggunakan model pembelajaran Problem Based
Instruction lebih baik, karena model pembelajaran Problem Based Instruction cocok digunakan dalam pembelajaran biologi khususnya pada materi sistem saraf. Dalam proses pembelajaran Problem Based Instruction siswa dapat berperan aktif pada proses pembelajaran selain itu juga model Problem Based Instruction lebih mengarahkan siswa pada penyelesaian masalah yang membutuhkan penyelesaian yang nyata. Sehingga membuat siswa dapat mengembangkan kemampuan berpikir kritisnya dan dapat mengaitkan materi kekehidupan seharihari.

Hal tersebut sesuai dengan pendapat Trianto (2009), menyatakan bahwa model Problem Based Instruction merupakan suatu model pembelajaran yang didasarkan pada suatu permasalahan yang membutuhkan penyelidikan autentik yakni penyelidikan yang membutuhkan penyelesaian nyata dari permasalahan yang nyata. Selain itu juga didukung oleh pendapat Purwaningsih (2013), Menyatakan bahwa model pembelajaran Problem Based Instruction (PBI) dikembangkan untuk membantu siswa mengembangkan kemampuan berpikir, pemecahan masalah dan ketrampilan intelektual, belajar berbagai peran, melalui pengalaman belajar dalam kehidupan nyata.

Ini menunjukan bahwa model pembelajaran Problem Based Instruction dapat meningkatkan kemampuan siswa berpikir kritis dalam pembelajaran biologi. Hal ini dikarenakan dalam model pembelajaran Problem Based Instruction siswa lebih termotivasi untuk terlibat secara aktif pada saat proses pembelajaran. Dengan menggunakan pembelajaran secara kelompok dapat mempermudah siswa dalam proses pemahaman materi, dan pemecahan masalah, selain itu model pembelajaran Problem Based Instruction juga menekan dan mendorong siswa untuk mampu berkomunikasi, merumuskan masalah, memberikan argumen, serta melakukan evaluasi. Sehingga hal tersebut dapat mengasah kemampuan siswa berpikir kritis pada saat proses pembelajaran berlangsung.

Hal ini didukung oleh pendapat Wati dan Hermanto (2015), Menyatakan bahwa pembelajaran menggunakan Model Problem Based Instruction adalah suatu proses pembelajaran yang menekankan pada keaktifan siswa, sehingga menekankan siswa untuk mampu berpikir kritis dalam penyajian masalah nyata yang terkait dengan materi yang akan dipelajari dan menemukan konsep untuk memecahkan masalah tersebut.

Selain itu di dukung juga oleh pendapat Dwijananti dan Yulianti (2010),

Bahwa model pembelajaran Problem Based Instuction tidak mengharapkan siswa hanya sekedar 
mendengarkan, mencatat, kemudian menghafal materi pelajaran, akan tetapi melalui model pembelajaran Problem Based Instuction siswa aktif berpikir, berkomunikasi, mencari dan mengolah data, dan akhirnya menyimpulkan.

pada kelas yang menggunakan model pembelajaran konvensional mendapat nilai rata-rata postes lebih rendah, dimana pada kelas yang menggunakan model konvensional yang diberi adalah model ceramah dan tanya jawab sehingga pada saat proses pembelajaran berlangsung siswa hanya menerima dan mendengar apa yang di terangkan guru, dan membuat siswa tidak dapat merumuskan masalah, memberikan argumen serta mengambil kesimpulan dari suatu permasalahan. Sehingga hal tersebut tidak dapat mengasah kemampuan berpikir kritis siswa pada saat proses pembelajaran berlangsung.

Hal ini juga didukung oleh pendapat sagala (dalam marnoko, 2011), yang menyatakan kelemahan model ceramah (konvensional) tidak dapat memberikan kesempatan untuk berdiskusi memecahkan masalah sehingga proses menyerap pengetahuan kurang tajam. Dan kurang memberikan kesempatan kepada peserta didik untuk mengembangkan keberanian mengemukakan pendapat (memberikan argumren).

Berdasarkan pada penelitian terdahulu, seperti pada penelitian Afrizon, dkk (2012), tentang Peningkatan Perilaku Berkarakter Dan Keterampilan Berpikir Kritis Siswa Kelas IX MTsN Model Padang Pada Mata Pelajaran IPA-Fisika Menggunakan Model Problem Based Instruction. Hasil penelitian menunjukan bahwa model Problem Based Instruction dalam pembelajaran IPA-Fisika selain dapat meningkatkan perilaku berkarakter siswa, tetapi juga mampu meningkatkan keterampilan berpikir kritis siswa. Karena model pembelajaran Problem Based Instruction tidak dirancang untuk membantu guru memberikan informasi sebanyak-banyaknya kepada siswa, melainkan untuk membantu siswa mengembangkan kemampuan berpikir, dan pemecahan masalah Ibrahim (dalam Trianto, 2009).

\section{SIMPULAN}

Berdasarkan hasil penelitian yang telah dilakukan dapat disimpulkan bahwa:

1. Terdapat penggaruh penggunaan model pembelajaran Problem Based Instruction terhadap kemampuan siswa berpikir kritis di kelas XI SMA Negeri 4 Kota Bengkulu.

2. Model pembelajaran Problem Based Instruction lebih efektif untuk meningkatkan kemampuan siswa berfikir kritis dibandingkan model pembelajaran Konvensional. Hal ini dapat dilihat dari nilai rata-rata tes akhir (postest) pada kelas XI IPS 3 (PBI) diperoleh nilai rata-rata 77,47. Sedangkan pada kelas XI IPS 2 (Konvensinal) diperoleh nilai rata-rata 70,27.

\section{DAFTAR PUSTAKA}

Agustina, S. 2011. Penerapan Model Problem Based Intruction (PBI) Untuk Meningkatkan Kecerdasan Psikomotorik Pada Pembelajaran Biologi Di SMP Negeri 4 Tebing Tinggi Kabupaten Empat Lawang. Skripsi. Universitas Muhammadyah Bengkulu. Bengkulu.

Baharuddin dan Wahyuni, NE. 2009. Teori Belajar Dan Pembelajaran. Ar-Ruzzmedia. Jogjakarta.

Dwijananti, P dan Yulianti, D. 2010. Pengembangan Kemampuan Berpikir Kritis Mahasiswa Melalui Pembelajaran Problem Based Intruction Pada Mata Kuliah Fisika Lingkungan. Jurnal pendidikan Fisika Indonesia 6 (2010) 108-114.

Fisher, A. 2009. Berfikir Kritis. Erlangga.

Hamalik, O. 1995. Kurikulum dan Pembelajaran. Bumi Aksara. Jakarta.

Hamdani, M.A. 2011. Strategi Belajar Mengajar. Pustaka Setia. Bandung.

Irwandi. 2009. Strategi Pembelajaran Biologi Berbasis Kontekstual. Universitas Muhammadyah Bengkulu. Bengkulu.

Sugiyono. 2013. Metode Penelitian Kuantitaf, Kualitatif, Dan $R \&$ D. Alfabeta. Bandung.

Trianto. 2009. Mendesain Model Pembelajaran Inovatif-Progresif. Kencana. Jakarta. 